\title{
PENDEKATAN DALAM STUDI ISLAM (Richard C. Martin)
}

\author{
Isnanita Noviya Andriyani \\ Keahlian Psikologi Pendidikan Islam \\ Dosen pada Program Studi Pendidikan Agama Islam STAIMS \\ Yogyakarta \\ Alamat e-mail : isnanita.87@gmail.com
}

\begin{abstract}
ABSTRAK
Islam mendapat perhatian besar dalam studi agama disebabkan karena perkembangan dan pengaruh global terhadap penduduk muslim dunia. Pemahaman tentang Islam sebagai agama dan pemahaman tentang agama dari sudut pandang Islam merupakan persoalan yang perlu dielaborasi dalam diskusi dan pembahasan di bidang studi agama. Kegagalan studi agama untuk membakukan diri sebagai suatu 'disiplin', meskipun banyak muncul studi agama. Posisi orang yang ingin bertanya "bagaimana" mempelajari Islam sebagai agama dibingungkan oleh kecenderungan pada kompartementalisasi di dalam pendidikan. Kegagalan studi agama untuk membakukan diri sebagai suatu disiplin keilmuan, tetapi prospeknya menjanjikan karena suatu saat dapat menjadi disiplin ilmu tersendiri dengan mengupayakan konsesnsus mengenai kurikulum, pemecahan masalah, dan kriteria capaian dan menjadi latar belakang akademik. Dari konteks akademik yang lebih sempit, maka apapun problem yang muncul adalah studi agama secara keseluruhan.
\end{abstract}

Kata kunci : studi islam, kompartementalisasi, interdisipliner, multidisipliner

\section{ABSTRACT}

Islam gained great attention in the study of religion due to the development and global influence on the world Muslim population. An understanding of Islam as a religion and understanding of religion from the viewpoint of Islam is an issue that needs to be elaborated in the discussion and the discussion in the field of religious studies. The failure of religious studies to standardize itself as a 'discipline', although many emerging religious studies. The position of those who want to ask "how" to learn Islam as a religion perplexed by tendencies on compartmentalization in education. The failure of religious studies to standardize itself as a scientific discipline, but the outlook is promising because someday they may be separate disciplines by seeking consensus regarding curriculum, 
Isnanita Noviya Andriyani : Pendekatan dalam Studi Islam (Richard C. Martin)

problem solving, and performance criteria and become academic background. From a more narrow academic context, so any problem that arises is the study of religion as a whole.

\section{Keywords : Islamic studies, compartmentalization,} interdisciplinary, multidisciplinary.

\section{A. Pendahuluan}

Perkembangan Islamic Studies mengalami perkembangan cukup signifikan, meskipun memiliki beragam alasan yang mendasarinya. Berbagai peristiwa di dunia Islam, baik di Timur Tengah maupun dunia Islam yang sangat luas mendorong untuk mempelajari dan menuliskan menjadikan Islam sebagai objek penelitian akademis. Begitu juga bagi masyarakat muslim sendiri, realitas keilmuan menuntut umat Islam dan lembaga pendidikan Islam menyadari dengan sungguh-sungguh terkait peran dan eksistensinya merespon problem-problem keagamaan. Oleh karena itu diperlukan studi yang mendalam tentang Islam. Selama ini Islam dipahami dalam pengertian historis dan doktriner. ${ }^{1}$

Kajian akademik terhadap Islam dalam diskursus kontemporer mengadaptasi metodologi dan epistemologi yang telah lama berkembang di Barat. Adaptasi terhadap metodologi keilmuan Barat menjadi sebuah keniscayaan sebagai perspektif atau cara pandang dalam melihat Islam. Perangkat paradigma, pendekatan dan metode berakumulasi dinamis dalam perkembangan ilmu pengetahuan tentang Islam.

Perkembangan terhadap studi Islam bagi para ilmuwan studi agama masih terbagi berdasarkan perspektif yang

1 Amin Abdullah, "Kata Pengantar," dalam Richard C. Martin, Pendekatan Terhadap Islam dalam Studi Agama, terj. Zakiyuddin Baidhawy, (Yogyakarta: Suka Press), hlm. vii. 
dibangun, maka pengajaran Islamic Studies terkesan menjadi dangkal, rentan terhadap konflik, tidak mendalam dan tidak komprehensif. ${ }^{2}$

Pandangan sejarawan agama, ilmuwan sosial, ataupun penganut Islam sendiri mengalami perbedaan yang cukup rumit. Para Islamis ataupun ahli agama terkadang mengalami kebuntuan ketika mendekati agama dari perspektif masingmasing. Belum lagi, Islamic Studies dari perspektif penganut, ada yang menganggap studi terhadap Islam telah baku sehingga tidak perlu lagi diperdebatkan.

Richard C. Martin mencoba mengelaborasi berbagai pendekatan terhadap Islam dalam buku yang disuntingnya Approaches to Islam in Religious Studies. Makalah ini mencoba mengupas tentang bagaimana pandangan Richard C. Martin terhadap studi Islam? Apa kontribusi Richard C. Martin dalam studi Islam secara umum?

\section{B. Pembahasan}

\section{Kerangka teori}

Membahas pemikiran Richard C. Martin tentang pendekatan terhadap Islam, tidak lepas dari pembahasan terhadap buku suntingannya Approach to Islam in Religious Studies. Di awal bab dari buku suntingannya, Richard C. Martin menjelaskan tentang Islam dan posisinya dalam studi agama. Menurut Richard C. Martin pemahaman tentang Islam sebagai agama dan pemahaman tentang agama dari sudut pandang Islam merupakan persoalan yang perlu dielaborasi dalam pembahasan dan diskusi pada bidang studi agama. Selanjutnya, Richard C. Martin membuka kemungkinan kontak dan pertemuan langsung

2 Amin Abdullah, "Kata Pengantar ...., hlm. xi. 
Isnanita Noviya Andriyani : Pendekatan dalam Studi Islam (Richard C. Martin)

antara tradisi berpikir keilmuan dalam Islamic Studies secara tradisional dan tradisi berpikir keilmuan dalam Religious Studies kontemporer yang telah menggunakan perangkat teori, metodologi dan pendekatan yang digunakan oleh ilmu-ilmu sosial dan humaniora yang berkembang sekitar abad ke-18 dan $19 .^{3}$

Buku yang disunting Richard C. Martin tersebut sarat dengan muatan metodologi. Dalam buku tersebut Richard C. Martin mencoba menunjukkan bahwa entitas historis Islam dengan segala variabel bisa didekati dengan berbagai pendekatan, diluar pendekatan "sakral" teologis yang sudah mentradisi sebelumnya. Dengan kelebihan dan kekurangan setiap pendekatan yang ditampilkan Richard C. Martin dalam buku tersebut, telah terbaca bahwa studi Islam tidak hanya menampilkan wajah dogmatis yang tegas, tetapi juga mempunyai sisi historis yang empirisobjektif, sosial dan juga kritis. Dengan demikian dapat terjadi kemungkinan diversifikasi pendekatan yang mungkin dilakukan oleh para pengkaji Islam, berbagai pendekatan yang ditawarkan perlu dituntaskan dengan dua wawasan baru, yaitu kajian interdisipliner dan multidisipliner yang memanfaatkan multi-pendekatan sebagai epistemologi dan metodologi kajian Islam, serta penegasan ontologi kajian Islam dengan pembedaan antara ranah 'Ulum al-Din, al-Fikr al-Islamy dan Dirasat Islamiyah. 4

3 Sokhi Huda, "Pendekatan terhadap Islam dalam Studi Agama dan Relevansinya dengan Studi Islam di Indonesia”, dalam Jurnal Religio Volume 1 Nomor 1, Maret 2011, hlm. 29.

4 Amin Abdullah, "Kata Pengantar" dalam Richard C. Martin, Pendekatan terhadap Islam dalam Studi Agama, terj. Zakiyuddin Baidhawy, (Yogyakarta: SUKA-Press UIN Sunan Kalijaga, 2010) hlm. viii-ix. 
Isnanita Noviya Andriyani : Pendekatan dalam Studi Islam (Richard C. Martin)

\section{Metode}

Richard C. Martin memberikan penjelasan bahwa bidang-bidang data (data fields) yang dikaji dalam buku Pendekatan terhadap Islam, merupakan data-data Islam yang tersebar luas secara historis dan geografis. Sifat datanya luas, dari tekstual ke sosio-historis sampai ritual simbolik. Buku tersebut dimaksudkan oleh Richard C. Martin memberikan kritik konstruktif terhadap pendekatan-pendekatan yang telah diterima dalam studi Islam dan upaya menerapkan metode dan teori dari disiplin lain pada data keagamaan Islam. Berbagai pendekatan tersebut disajikan dengan tujuan memberikan layanan akan perubahan dan perbaikan dalam studi Islam sebagai agama. 5

Richard C. Martin membingkai bidang data (data fields) menjadi dua kelompok. Bagian pertama sampai bagian keempat mempersoalkan studi agama. Bagian kelima menyajikan dua respon yang berbeda dari penulis tentang Islam (perspektif insider dan perspektif otsider). Sehingga diharapkan secara bersama-sama bab yang disusun membentuk sebuah percakapan dan diskusi tentang Islam dan studi agama dengan harapan mampu memberikan perhatian serius terhadap Islam dan studi agama. ${ }^{6}$

5 Richard C. Martin, "Islam dan Studi Agama: Sebuah Catatan Pengantar", dalam Pendekatan terhadap Islam dalam Studi Agama, terj. Zakiyuddin Baidhawy, (Yogyakarta: SUKA-Press UIN Sunan Kalijaga, 2010), hlm. 19.

6 Richard C. Martin, "Islam dan Studi Agama: Sebuah Catatan Pengantar", dalam Pendekatan terhadap Islam dalam Studi Agama, terj. Zakiyuddin Baidhawy, (Yogyakarta: SUKA-Press UIN Sunan Kalijaga, 2010), hlm. 19. 
Isnanita Noviya Andriyani : Pendekatan dalam Studi Islam (Richard C. Martin)

\section{Konsep dasar}

Richard C. Martin secara umum melihat suatu agama bukan hanya dari insider, yaitu pemeluk dan pengikut agamanya seperti Islam dengan komunitas muslimnya, namun juga melihat agama dari pandangan outsider, yaitu orang-orang yang mempelajari Islam dari kalangan nonmuslim atau sering dikenal dengan Islamist. ${ }^{7}$

a. pendekatan terhadap teks kitab suci dan nabi (approach to scripture and prophet)

Richard C. Martin mengunakan tiga pendekatan dalam studi Al-Qur'an (skripture). Pertama, teori speechact dalam hubungannya dengan dimensi lisan dan kesusasteraan dari pembicara/situasi sumber dalam mendefinisikan Al-Qur'an sebagai tradisi oral/lisan. Kedua, simbolisme kosmologi Al-Qur'an dalam konteks khusus speech-act dari tipe lingua sacra. Ketiga, menelaah metode analisis oral-formulatic dan semanticonstituent yang sukses diaplikasikan dalam teks non AlQur'an. ${ }^{8}$

b. pendekatan terhadap ritual dan komunitas (approach to ritual and community)

Richard C. Martin berpendapat bahwa cakupan studi-studi ritual yang lebih baru sebagaimana

7 Sokhi Huda, "Pendekatan terhadap Islam dalam Studi Agama dan Relevansinya dengan Studi Islam di Indonesia", dalam Jurnal Religio volume 1 Nomor 1, Maret 2011, hlm. 29.

8 Dalam tulisannya Richard C. Martin mengemukakan pendekatannya dalam studi Al-Qur'an: "In the remainder of this essay I will discuss three aspects of a new approach to Quranic studies. First, I will discuss speech-act theory in relation to the oral and literary dimensions of the speaker/addressee situations that define the Qur'an as speech act. Second, I will discuss the symbolism of Quranic cosmology as a special context of speech acts of the lingua sacra type. Third, I will review oral-formulaic and semantic-constituent methods of analysis which have been successfully applied to non-Quranic texts." 
diterapkan pada Islam dapat memperkaya pemahaman tentang topik tradisional dalam studi Islam. Ta'ziyah Syi'ah, Tariqah Sufi, ziarah ke makam orang suci untuk memperoleh berkah, membaca Al-Qur'an, dan sebagainya merupakan aktifitas simbolik yang signifikansinya mendalam dalam Islam. Studi agama bukanlah mencari apakah ritual itu terdapat dalam Islam, melainkan bagaimana mendekati studi aneka macam aktifitas ritual di dalam Islam. Pendekatan terhadap ritual sebagai perilaku yang terstruktur dan bermakna dalam budaya Islam. Frederick M. Denny menulis Islamic Ritual: Perspectives and Theories (Ritual Islam: Perspektif dan Teori) mengawali kajiannnya dengan menguji mengapa para Islamis mengabaikan aspek yang sangat performatif dalam kewajiban keagamaan Islam. Terhadap problem tersebut, Denny menawarkan kemungkinan riset masa depan dan caracara mendekati aneka bentuk dan ekspresi aktifitas simbolik dalam masyarakat Islam. ${ }^{9}$

c. pendekatan terhadap islam dan masyarakatnya (approach to religion and society).

Pada pendekatan terhadap agama dan masyarakat, buku yang di editori oleh Richard C. Martin terdapat sumbangan Antropolog Marilyn R. Waldman yang menunjukkan transmisi sosial budaya dengan sarana literer yang bertentangan dengan oral adalah keduanya berguna untuk menyusun pertanyaan yang berbedabeda tentang Islam.

9 Richard C. Martin, Pendahuluan bagian 2, dalam Pendekatan terhadap Islam dalam Studi Agama ..., hlm. 67. 
Marilyn R. Waldman melihat bahwa penekanan studi terhadap Islam klasik yang telah terjadi pada pertumbuhan tradisi literer, institusi pembelajaran dan seterusnya menjadikan studi agama mengesampingkan komponen oral budaya muslim, misalnya dalam kasus Al-Qur'an. Marilyn R. Waldman juga mengemukakan bahwa terjadi pergeseran dari model (oral) "yang tak terdaftar" ke model transmisi (literer) "yang terdaftar" membantu dalam memahami perkembangan masyarakat Islam. ${ }^{10}$

d. pendekatan terhadap interpretasi (scholarship and interpretation).

Pendekatan terhadap interpretasi menggunakan pendekatan filosofis keilmuan dan hermeneutik yang di tulis oleh Charles J. Adam, Andrew Rippin dan Azim Nanji. Charles J. Adam menguji karya Henry Corbin tentang Islam di Iran (Islam Syi'ah) dengan menggunakan pendekatan interpretatif dari Clifford Geertz, yaitu deskripsi tentang fakta (thick description). Sedangkan Andrew Rippin membahas analisis literer yang pernah di terapkan dalam Bible.

Andrew Rippin memunculkan dua persoalan untuk thick description, yaitu persoalan cara memandang dan mendekati sejumlah data yang akan diinterpretasi. Kemudian Azim Nanji memberi perhatian pada problem analisis simbol budaya dan maknanya yang ada dalam data agama, yaitu materi sastra suci Syi'ah Ismailiyah. Azim Nanji mendekati materi suci dalam Syi'ah

10 Richard C. Martin, Pendahuluan bagian 3, dalam Pendekatan terhadap Islam, hlm. 88. 
Isnanita Noviya Andriyani : Pendekatan dalam Studi Islam (Richard C. Martin)

Ismailiyah dengan teori sastra dan analisis tematik untuk menentukan pesan Islam fundamental dalam karya-karya tafsir.

e. Pendekatan terhadap problem insider dan outsider.

Pada masalah insider ${ }^{11}$ dan outsider ${ }^{12}$, Richard $\mathrm{C}$. Martin menyunting tulisan Muhammad Abdul Rauf, Outsider's Interpretations of Islam: A Muslim point of View (interpretasi orang luar tentang Islam: sudut pandang muslim) dan Fazlur Rahman, Approaches to Islam in Religious Studies: Review Essay (Pendekatan terhadap Islam dalam studi agama: Catatan Resensi). Pendekatan yang digunakan pada problem insider dan outsider merupakan pendekatan kritis. Menurut Richard C. Martin pendekatan kritis atas problem insider dan outsider yang dikaji dua penulis tersebut memiliki dampak yang luar biasa atas studi Islam terhadap akademik di Amerika Utara. ${ }^{13}$

\section{Kontribusi untuk ilmu pengetahuan}

Pemikiran Richard C. Martin tentang studi Islam berbasis pada bidang-bidang data sebagai fokus kajian. Berdasarkan bidang-bidang data yang dipaparkan Richard C. Martin, maka dapat diklasifikasikan ke dalam tujuh perspektif pendekatan, yaitu 1) Pendekatan Tekstual, 2) Pendekatan Sejarah, 3) Pendekatan Sosiologi, 4)

${ }^{11}$ Insider adalah para pengkaji Islam dari kalangan muslim sendiri.

12 Outsider adalah sebutan untuk para pengkaji non-muslim yang mempelajari Islam dan menafsirkannya dalam bentuk analisis-analisis dengan metodologis tertentu.

13 Richard C. Martin, "Bagian 5 tantangan dan kritik" dalam pendekatan terhadap Islam ..., hlm. 187. 
Pendekatan Antropologi, 5) Pendekatan Filsafat Ilmu, 6) Pendekatan Hermeneutik dan 7) Pendekatan Kritis. ${ }^{14}$

Melalui buku suntingannya Richard C. Martin memberikan kontribusi dua hal terhadap Islamic Studies. Pertama, pengungkapan terhadap isu-isu studi agama. Kedua presentasi respon-respon para penulis muslim terkenal tentang Islam. Sedangkan kata kunci penting yang dimunculkan adalah bidang data. Maka dapat dipahami bahwa pemberian judul buku suntingannya "Approaches to Islam in Religious Studies", bukan "Approaches of Islamic Studies” ataupun “Approaches for Islamic Studies”.

\section{Kesimpulan}

Dalam pendekatan terhadap Islam, Richard C. Martin ingin membuka peluang kontak antara tradisi berpikir keilmuan antara Islamic studies tradisional dan tradisi berpikir religious studies kontemporer dengan memanfaatkan kerangka teori, metodologi dan pendekatan yang digunakan oleh ilmu-ilmu sosial dan humaniora (sosiologi, antropologi, filsafat ilmu, hermeuetik dan sebagainya) yang berkembang sekitar abad ke-18 dan 19.

Basis kajian Richard C. Martin menggunakan data fields, yaitu bidang-bidang data tentang Islam yang tersebar luas secara historis dan geografis. Adapun jenis-jenis datanya dari data tekstual, ritual-simbolis, hingga sosial-historis. Richard C. Martin mempresentasikan kritik konstruktif terhadap studi Islam dan menggunakan perangkat ilmiah interdisipliner dan multidisipliner terhadap data keagamaan

14 Sokhi Huda, "Pendekatan Terhadap Islam dalam studi agama dan relevansinya dengan studi islam di indonesia" dalam Jurnal Religio, vol.1 no.1. Maret 2011, hlm. 35. 
Isnanita Noviya Andriyani : Pendekatan dalam Studi Islam (Richard C. Martin)

Islam dengan tujuan memberikan perubahan dan pengembangan terhadap studi Islam sebagai agama. 
Isnanita Noviya Andriyani : Pendekatan dalam Studi Islam (Richard C. Martin)

\section{DAFTAR PUSTAKA}

Abuddin Nata, Metodologi Studi Islam, (Jakarta: PT. Raja Grafindo Persada, Cetakan ke-7, 2002).

Amin Abdullah, Studi Agama Normativitas atau Historisitas, (Yogyakarta: Pustaka Pelajar, Cetakan ke-1, 1996).

Atho' Mudzhar, Pendekatan Studi Islam, (Yogyakarta: Pustaka Pelajar, Cetakan ke-3, 2001).

Mukti Ali, Memahami Beberapa Aspek Ajaran Islam, (Bandung: Mizan, Cetakan ke-3, 1996).

Peter Connolly (ed.), Aneka Pendekatan Studi Agama (terj.) dari judul asli "Approaches to the Study of Religion", (Yogyakarta: LKIS, 2002).

Richard C. Martin, "Understanding the Qur'an in Text and Context", dalam History of Religion, Vol. 21, No. 4 (May, 1982).

, Defenders of Reason in Islam: Mu'tazilism from Medieval School to Modern Symbol, co-author Mark R. Woodward dan Dwi S. Atmaja, (London: Oneworld, 1997).

, Approaches to Islam in Religious Studies, terjemahan Zakiyuddin Baedhowi, Pendekatan terhadap Islam dalam Studi Agama, (Yogyakarta: SUKA Press, 2010).

, "Hidden Bodies in Islam: Secular Muslim Identities in Modern (and Premodern) societies" dalam Gabrielle Marranci (editor) Muslim Societies and Challenge of Secularization: An Interdisiplinary Approach, (New York: Springer Science+Business Media. B.V, 2010).

Richard C. Martin dan Abbas Barzegar (Editor), Islamism: Contested Perspective on Political Islam, (Carolina: Stanford University Press, 2010).

Sokhi Huda, "Pendekatan terhadap Islam dalam Studi Agama dan Relevansinya dengan Studi Islam di Indonesia”, dalam Jurnal Religio Volume 1 Nomor 1, Maret 2011.

Taufik Abdullah, Metodologi Penelitian Agama Sebuah Pengantar, (Yogyakarta: Tiara Wacana, 1989) 